MAUNO KoskI

\title{
Kylien ja maatilojen nimien vaihtumisesta ja muuttumisesta eräissä Lounais- Suomen pitäjissä
}

Tämän esityksen aineisto on otettu pääasiassa Arvo MEREN, sittemmin LOPMEREN, teoksesta Vanhan Vehmaan kihlakunnan pitäjien ja kylien nimet $I-I I{ }^{1}$. Paikannimiarkiston kokoelmista (PNA) ja minun keräämistäni kokoelmista, jotka käsittävät Lemun, Askaisten, Merimaskun, Maskun ja Raision pitäjät. Asiakirjamerkinnät on saatu Turun Maakunta-arkiston kokoelmista. Tämä aineisto muutamine satunnaisine lisäyksineen riittänee antamaan käsityksen siitä, miten kylien ja maatilojen nimet ovat muuttuneet Iounaismurteitten Turun pohjoispuolisella alueella.

Kylien ja niihin rinnastettavien vanhojen yksinäistilojen nimien tarkastelu voidaan aloittaa siltä yleisesti tunnetulta pohjalta, että ne ovat yleensä pysyneet muuttumattomina ainakin koko sen ajan, jolta asiakirjamerkintöjä on olemassa. Säännöllisiä kylännimiluetteloja (tässä esityksessä käytetään termiä 'kylännimi" myös vanhoista yksinäistiloista puhuttaessa), tilikirjoja, on säilynyt vuodesta 1540 alkaen. Jo vanhimmissa tilikirjoissa on kylillä yleensä samat nimet kuin nykyäänkin. Muutamista kylistä on tilapäisiä merkintöjä aina 1300-luvulta alkaen 2. Nämä tukevat sitä käsitystä, että kylännimet olivat jo pitkin keskiaikaa samoja kuin myöhemminkin.

1 ARvo Meri, Vanhan Vehmaan kihlakunnan pitäjien ja kylien nimet $I$, Entisten Laitilan, Lapin ja Uudenkirkon pitäjien alue. Helsinki 1943 (MERI). J. A. LopMrri, ed. teos II, Entisten Taivassalon ja Vehmaan pitäjien alue. Helsinki 1947 (LOPMERI).

2 Registrum Ecclesiæ Aboensis eller Åbo domkyrkans svartbok. Toim. REINHOLD HAUSEN. Helsingfors 1890 (REA) ; Finlands medeltidsurkunder IVIIT. Toim. ReInhoLd Hausen. Helsingfors 1910-1935 (FMU). 
Suurin nimeä kohtaava muutos on sen täydellinen vaihtu$\mathrm{m}$ in e $\mathrm{n}$ toiseksi; uuden nimen aihe on toinen kuin vanhan. Laitilassa on yksinäistilan nimi Uusikartano muuttunut nimeksi H a r tikka la. MERI (s. 31-32) selittää, että vaihtumisen aiheena on ollut tilan omistaja Hartikka Jaakonpoika Garp (asiakirjoissa 1540-1580-luvuilla). Eurajoella on yksinäistila, josta on käytetty 1500-luvulta asti kahta nimeä, $\mathrm{V}$ a i m a la ja $\mathrm{K}$ a r r a. Velkualla on kylännimi $\mathrm{V}$ al (k)k o vaihtunut 1600-luvun ensimmäisellä puoliskolla nimeksi $\mathrm{Ti}$ urla (Lopmeri, s. 170, 181-182). Tiurla on alkuaan ollut Valkon kylään kuuluva maatila. Kysymyksessä on kylän hajoaminen, sillä Valkon kylään myös kuuluneesta tilasta, Krööpilästä, on tullut yksinäistila (MK 31690 Walko eller Kröpilä och Tiurla). Tiurla sen sijaan on säilynyt pari tilaa käsittävänä kylänä. Alkuperäistä kylännimeä, Valkoa, ei enää kansan keskuudessa tunneta.

Pyhässärannassa on tapahtunut tällainen vaihdos: MK 1540 Ojala, VA 49141542 Oÿalabı̈, 1650 Wärknäsudd olim Rictanemi, Rictamäcki (edellinen suomalaisista nimistä näyttää tarkoittavan nientä, jälkimmäinen tilaa) ${ }^{5}$. Kirkonkirja v. 1693-1701 Richtmäki, 1711-19 Richtamäki, kastek. 1732 Rihtniemi, kauppakirja v:Ita 1761 Åja eller Richtnjemi, Ijk ${ }^{6} 1769$ Rihtimäki by, 1810 Rihtiniemi, nyk. rihtmäkì rihtmäniäm. Paitsi että nimi on vaihtunut, on uuttakin nimeä kahta lajia, ja nykymurteessa on vielä näitten kontaminaatiomuoto. Paikka on ollut Rihtniemenä tunnetumpi kuin Oja(la)n kylänä. Rihtniemi tunnetaan mm. useista kansantarinoista. 7

Kun paikkaa ruvetaan kutsumaan jollakin nimellä, on siihen yhtenä tärkeimpänä syynä halu tehdä selväksi, mistä samaan luokkaan kuuluvista paikoista on puhe. Kunkin paikan nimi tunnetaan vain tietyllä alueella. Voidaan teorioida, että jokaisen nimen ympärille muodostuu piiri nuistä ihmisistä, jotka joutuvat käyttämään nimeä jokapäiväisessä elämässään. Tällaista voidaan sanoa n i m e nkäyttöpiiriksi. Pienimmän nimenkäyttöpiirin muodostavat

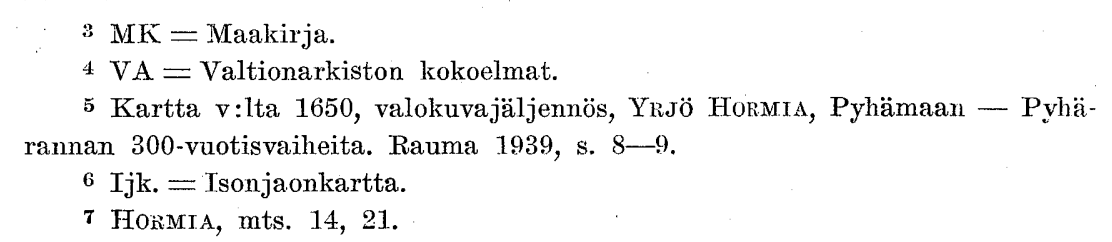


tavallisesti maatilan alueella elävät ihmiset. Maatilan piiriin rajoittuvat tavallisesti agraarinimet ja pienehköjen maastonkohtien nimet, vaikka joissakin tapauksissa tällaisten nimien käyttöpiirinä on koko kylä. Nimen rajoittuminen kylän tai siihen kuuluvan maatilan piiriin riippuu talojen ja tilojen alueitten asemasta, toisiinsa verrattuna ja kyläläisten keskisestä kanssakäymisestä. Joskus tiedetään tarkalleen kaikki naapurin alueella olevat nimet, joskus vain joku omituinen tai ympäristöstään selvästi erottuvan paikan nimi. Tällainen nimi tunnetaan joskus kylän ulkopuolellakin. Joskus näitten käyttöpiiri ulottuu läheisiin naapuripitäjän kyliinkin. Kylien nimien käyttöpiiri on tavallisesti pitäjän alue usein lähimpine ympäristöineen. On oletettavissa, että se kuitenkin alkuaan on ollut pitäjää pienempi; sen lienee aluksi muodostanut vain lähin naapuristo. (Kylät ovat tavallisesti muodostuneet maatiloista jakautumalla.) Nimenkäyttöpiiri ei suinkaan ole muuttumaton, vaan useinkin se laajenee sitä mukaa kuin ihmisten välinen kanssakäyminen kasvaa. Varsinkin kylännimien kohdalla on tässä suhteessa merkittävä se vaihe, jolloin pitäjä on muodostunut sekä hallinnollisten että kirkollisten tekijöitten vaikutuksesta suhteellisen kiinteäksi sosiaaliseksi piiriksi. Näin on kylien nimien käyttöpiiri laajentunut lähimmästä naapuristosta koko pitäjän käsittäväksi.

Joissakin tapauksissa on saman pitäjän eri puolille syntynyt samanlaisia kylännimiä. Ainakaan tätä esitystä varten tutkitulla alueella eivät tällaiset nimet ole sellaisinaan säilyneet, vaan niihin tai ainakin toiseen niistä on tullut jokin muutos.

Kylännimissä kehitys kulkee tavallisesti siten, että kahden samanlaisen (mahdollisesti usein yhteistä alkuperääkin olevan) nimen jouduttua samaan käyttöpiiriin (ts. samat ihmiset joutuvat puhumaan molemmista) nimeen lisätään jotain, tavallisesti prefiksi tai mu määrite alkuun. Näin on Raisiossa J oki-S y lttylä ja Mets äSylttylä (VA $1791 \quad 1616$ Merisylttilä), Maskussa PiuhaIiroinen ja Korpi-Iiroinen, Vehmaalla MannerKaisti ja Salmen-Kaisti. Yleensä näiden kylien läheisyydessä käytetään vain nimen alkuperäistä jälkiosaa, varsinkin jos puheesta käy selville, että tarkoitetaan juuri lähinnä olevaa paikkaa. Hiukan enemmän nimien alkuperäistä asua on järkyttänyt samasta syystä tapahtunut kehitys Lemun ja Askaisten (ent. Lemun kappeli) J är risten kylien jouduttua samaan nimenkäyttöpiiriin. 
Meren rannalla ja etelämpänä (murteessa meri 'etelä') olevasta Askaisten Järvisestä on tullut M e r i järvi ja Lemun Järvisestä M a nnerjärvi (Kl.8 1676 Merijärffwi ja Järffwis, henkikirja 1676 Jerfwis ja Manner Jerfwi). Molemmista käytettiin vielä 1600luvun puolenvälin asiakirjoissa Järvis-merkintää. Lemulaisella on

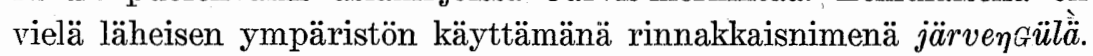

Edellä olevissa esimerkeissä esitellyt alkuaan samannimiset paikat sijaitsevat eri puolilla pitäjää. Asutushistorialliselta kannalta näitten mahdollisesta yhteenkuuluvuudesta on enää mahdoton sanoa mitään. Jos näistä toinen on toisen ulkotila tms., voitaisiin nimen muutosta pitää kuuluvana lähinnä siihen tyyppiin, joka esiintyy joskus tilan jakautuessa kahdeksi, esim. Pelto-Klemelä ja Kylä-Klemelä Raisiossa.

Joskus samakantaiset nimet saattavat kuulua aivan vierekkäisillekin kylille. Lemussa on Is o-V a ll u n en ja $V$ ä hä-V a 11 un e n. Tässä tapauksessa on todennäköisesti alkuaan yhdestä kylästä kysymys. Kalannissa on alkuaan ollut $\mathrm{K}$ o r p i a in en, MK 1540 Korpias, 1542, 1543, 1545, 1555 Korpiais, 1549 isokorp ÿ, 1555 ninikorbi, 1556 ninikorpi, kk.9 1749 - 57 Kårwenkylä, nyk. I s o k o r p i. Tämän vieressä on Jakkolankorpi l. Vähäkorpi (yl. puheessa), 1411 (1621) Kårfwis, 1417 Laffrens ja oleff Koruelte, 1540 Korffuenkylä, 1556 Jaconkorbi, 1692 Jacolankårpi, 1722, kk. 1720 -34 Corwenkylä eller Jacolancorpi.10 Tuntuu siltä, että molempien kantana on alkuaan ollut kulmakunnan nimi ja että asutus on tapahtunut eri kylistä päin, jolloin aivan ensi vaiheessa nimien käyttöpiirit eivät ole kuuluneet yhteen. Kummankin nimen runsaat muunnokset osoittavat, että kahden samanlaisen tai ainakin samantapaisen nimen ilmestyminen toistensa naapureiksi ja sitä luonnollisesti seurannut nimenkäyttöpiirien osittainen yhtyminen on järkyttänyt käytäntöä, jonka mukaan samojen ihmisten muodostamassa nimenkäyttöpiirissä ei voi olla kahta samanlaista nimeä.

Varsinkin niillä alueilla, joilla suomenkielinen ja .ruotsinkielinen asutus kohtaavat toisensa, on kylillä usein sekä suomenkielinen että ruotsinkielinen nimi. Muutamissa tapauksissa nimillä ei ole keske-

\footnotetext{
$8 \mathrm{Kl} .=\mathrm{Kymmenysveroluettelo.}$

$9 \mathrm{kk} .=$ kirkonkirja (1. rippikirja).

10 MERI, s. $43,44$.
} 
nään mitään merkitysyhteyttä. Kustavissa on Stansholm, MK 1546 Staffansholm, suomeksi K e v o i, kevò, kk. 1727-35 Standsholm elr Kepo. Kevoi on yksi kylän tiloista; tässä siis taas on yksityisen tilan nimi siirtynyt merkitsemään koko kylää. Se, että kylällä on sama nimi kuin jollakin kylän tilalla, ei ole kovin harvinaista. Kustavin Koilassa (< Koivulahti) oli 1700-luvulla tilojen niminä Vähätalo ja Koila. (ilmeisesti alkuperäinen kantatila). Kustavissa on kylännimi Kaitainen, kk. 1696-1709 Caitais, ruots. Östansjö (MK 1540 Östansöö). Askaisissa on Louhisa ri (VA $693^{\mathrm{a}} 1557$ Lounazari), ruots. Villn äs.11 Vielä on Kustavissa $\mathrm{K} u \mathrm{n} \mathrm{n}$ ara in e $\mathrm{n}$ (FMU 1380 Gunnarsby), ruots. F a g e rn äs (Tk.12 1694 Fagernäs). Molemmilla nimillä on ruotsalainen alkuperä. Ruotsalainen nimi on mukautunut suomalaiseen äänneasuun ja vieläpä suomalaiseen nimityyppiinkin (-inen). Edellä olevissa tapaukississa nimenkäyttöpiirit ovat muodostuneet kielisuhteitten mukaan. On vaikea päätellä, missä määrin nimet ovat olleet voimassa yli kielirajan, kun molempia kieliryhmiä varten on oma nimi.13 Vertailukohteeksi tässä voidaan ottaa pitäjännimi Mynämäki, josta ruotsinkieliset käyttävät nimeä Virmo. Virmo-nimestä on jälki suomalaisessakin nimistössä; Lemussa on Mietoisiin, entiseen Mynämäen kappeliin johtavalla tiellä virmovミrıjä.

Koska tutkimusmateriaalina olleista yli kuudestasadasta nimestä on löytynyt näin vähän vaihtumista, voidaan hyvällä syyllä katsoa oikeaksi se jo ennestään tunnettu käsitys, että kylännimet ovat yleensä perusainekseltaan säilyneet. Huomattavasti yleisempää on se, että nimen asu on $m u u t t u n u t$. Useimmiten tämä tapahtuu murteessa vaikuttavien äännelakien (esim. redusoituminen, sisä- ja loppuheitto) vaikutuksesta. Joskus muutos on mennyt niin pitkälle, että alkuperäistä merkitystä ei enää voidakaan huomata. Tätäkin pitemmälle voidaan kehityksen sanoa menneen niissä tapauksissa, joissa uudella, aikaisemmasta foneettisesti kehittyneellä asulla on

11 1564. Wilnäs (Bidrag till Finlands historia - BFH -, Toim. ReInIr. HAU SEN. Helsingfors 1881-1917).

$12 \mathrm{Tk} .=$ Tiluskartta.

13 AULIS OJA luettelee Turun idänpuoliselta lounaismurteiden alueelta muutamia kylännimiä, joissa alkuperäinen suomalainen nimi on muutettu ruotsalaiseksi joko aivan uusin perustein tai kääntämällä. AULIs OJA, Keskiaikaisen "Etelä-Suomen" asutus ja aluejaot. Helsinki 1955, s. 38. 
kielessä merkitysvastine. Nimen aiheen muutos on tapahtunut ikään kuin vahingossa.

Tarkasteltavana olevalla alueella on suuri joukko nimiä, jotka alkuaan ovat olleet laksi-loppuisia yhdyssanoja (nyk. -lahti), mutta joista loppu on kulunut pois, niin että jäljelle on jäänyt yksiosainen la-loppuinen nimi. Kehitys on siis aiheuttanut näennäisen siirtymisen luontonimityypistä varsinaiseen asumusnimityyppiin. MeRr luettelee näitä omalta alueeltaan 15 (s. 14-15). Näistä on 14 vanhoista Vehmaan ja Taivassalon suurpitäjistä ja vain yksi pohjoisemmalta alueelta, Kalannista. Entisellä Laitilan, Lapin ja Uudenkirkon (= Kalanti) pitäjien alueelta on kaksi nimeä, joissa -lahti (< laksi) on säilynyt, nim. Pyhänrannan Hirslahti ja Kalannin Torlahti. Vanhoissa Vehmaan ja Taivassalon suurpitäjissä ei ole säilynyt yhtään lahti-loppuista kylännimeä. Pisimmälle kehitys on mennyt kustavilaisessa nimessä Koijffulax (MK 1540) > koila. Rymättylässä on 1500-luvulla mainituista kuudesta laksi-loppuisesta nimestä säilynyt yksi, ja kolme on lyhentynyt (kaksi kylää on kadonnut): MK 1540 Sandalax > santala, MK 1540 Sarlax > sārla, 1557 Raulax > raula, MK 1540 Leÿkilax > leiklahti.14 Merimaskussa on Ku uslahti säilynyt (FMU 1466). Luonnonmaalla (Naantalin mlk.) on Kuivalahti säilynyt (MK 1540 Kuÿulax), samoin Askaisissa Santalahti ja Vuorlahti.15 Hirvensalossa (vanhaa Maarian pitäjää) on vanha Haaralahti (REA 1440 Haralax, MK 1540 ja 1684 Harlax) lyhentynyt asuun H a a r 1 a. Lounaismurteitten itäryhmän alueen monista tähän tyyppiin kuuluvista nimistä ovat melkein kaikki säilyttäneet loppunsa. Poikkeuksen tekevät Perniön Arpalahti, jolla on rinnakkaismuotona Arpala, ja Piikkiön Aerla.16 Po. nimistä on ensin $i$ joutunut loppuheiton alaiseksi; sen jälkeen nimet ovat analogisesti sekaantuneet huomattavasti yleisempään la-johtimiseen tyyppiin, ja loppukonso-

\footnotetext{
14 Keijo SanTaLahti, Merimaskun ja Rymättylän kylien, talojen ja asumusten nimet vuoteen 1906. Laudaturtyö n:o 255. Turun Yliopisto.

15 MaUno Koski, Askaisten asumusnimistö. Varsinais-Suomen Maakuntakirja 14-15. Turku 1957. s. 122, 123.

16 Suomenmaa III; MK 1540 Arpala, 1684 Arpalax Perniössä ja FMU 1377 Arialum, 1466 Arelaby, 1451 Adhrelax, MK 1540 Ayriala, 1684 Ahrlax, henkik. 1879 Aerla Piikkiössä. 
nantit ovat kadonneet.17 On selvästi havaittavissa, että näin pitkälle johtaneen kehityksen keskus on Taivassalon ja Vehmaan murrealueella, josta ilmiö on levinnyt Rymättylään. Nimet ovat säilyneet Askaisten-Merimaskun alueella todennäköisesti siksi, että siellä ei loppuheitto ole niin yleistä kuin naapurissa, Taivassalon ja Vehmaan seuduilla. Em. alueella on $i$ vieläkin säilyneenä (vuarlahti). Laitilaa voitaisiin pitää -laksi $>$-la -alueen periferiana. Toinen mahdollisuus on, että siellä ainoana oleva ko. kehityksen tulos on syntynyt erillään muista. Näin on ainakin Perniön Arpala(hde)n ja mahdollisesti Piikkiön Aerlankin laita. Kirjurinetymologia on mahdollinen selitys.

Vielä on koko joukko nimiä, joissa tapahtunut äänteellinen kehitys on hävittänyt alkuperäisen merkityksen. Maskussa on Kil1 invahasta vähitellen tullut Killuva, MK 1540 Kÿllÿnuaha, 1671 ja 1701 Killwaha, 1722 Killuwaha, Kl. 1710 Killua. Paikannimissä varsinkin ensimmäistä tavua kauempana slevat vokaalit roivat helposti vaihtua. Nimi on tällä vuosisadalla vırallisesti palautettu alkuperäiseen muotoonsa.

Kansanetymologialla on ollut osansa, kun vehmaalaisesta nimestä La ukkapelto (REA 1477 Lawkapelto, samaan ääntämiseen viittaava merkintä on yleensä kaikissa asiakirjoissa) on puhekielessä tullut lautpelto (LoPMerr, s. 98). Kalannissa on ilmo, FMU 1411 Inhamå (tähän viittaavat muutkin asiakirjamerkinnät), mutta Ijp.18 1772 Ilmo. Virallinen nimi on edelleenkin Inhamo. Merimaskussa on kaukalo, asiakirjojen Kaukola (MK 1540), vasta 1700luvulla Kaukalo (kk. 1735-45). Voi olla niin, että Kaukolamerkinnät ovat vain kirjurin etymologiaa, mutta yhtä hyvin kysymyksessä saattaa olla kansan suussa syntynyt väännös.

Askaisissa on $\mathrm{L}$ o $\mathrm{u} \mathrm{h}$ i s a a r i, louh (i) säri loussāri,19 josta merkinnät ovat seuraavat: VA 693a 1557 Lounazari, VA 7961559 Lounessari, VA 9061561 Lounassari Lounssari, BFH 1562 Lougnesary, v. 1741: "...prædium Wilnäs, qvod etiam fennice Lous Saari quasi SAAR Lovis audis."20 SAAR Lovis mainitaan saman teoksen

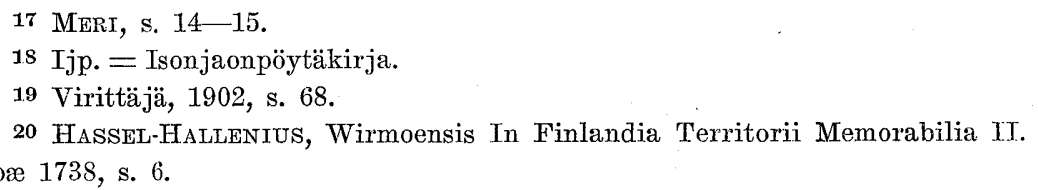
Aboæ 1738 , s. 6. 
v. 1738 ilmestyneessä ensimmäisessä osassa.21 Lemun Mattilan Ijk:ssa $\vee .1811$ on Loussare äng, joka merkitsee Louhisaaren omistamaa niittyä. Asiakirjamerkinnöistä päätellen on Lounassaari (tai Lounatsaari rinnakkaismuotona) ollut nimen alkuperäinen muoto.22

Lokalahdella on pätìlh, REA 1477 Pessenalgo, MK 1540 Pätzinalho, kirkontili v:lta 1690 Piezenalho, kk. 1747-54 Pietinalho (LopmerI, s. 118, 119), jälkimmäinen asu on osittain vakiintumassa puhekieleenkin; joka tapauksessa se on nykyään virallinen nimi. Kirjurillakin saattaa olla tässä osuutensa.

Vielä muutama esimerkki siitä, miten nimi saattaa kuluessaan muuttua niin, että alkuperäinen merkitys katoaa: Kalannissa on haoðsāur haosār, FMU 1411 (1621) Haudoinsari, FMU 1530 Hauansar̈̈, kk. 1735—48 Haudonsari (MERI, s. 33). Uudenkaupungin pitäjässä on putsār yleensä vanhoissa asiakirjoissa Putkisaari (MERI, s. 132). Molemmissa on alkuosassa tapahtunut loppuheitto, edellisessä genetiivin $n$ on sitä ennen kadonnut. Kalannissa on Kolis e va, kolsa, MK 1540 Kolisoffua, VA 5851555 Kolisepa, kk. 1800 Koliseva (MErr, s. 74). Tässä on päässyt sisäheitto vaikuttamaan, samoin Pyhässärannassa MK 1540 Rë̈dula >* reiðla > reila (MERI, 138-139).

On nimiä, joissa eri asiakirjamerkintöjen ja nykyisen muodon välillä on sellaisia ristiriitoja, että alkuperäistä muotoa on mahdoton täsmälleen rekonstruoida. Kalannissa on piälä, FMU 1465 (1551) Peiulæ J: Penilæ, MK 1540 Peuele, samanlaista merkintää on suurimmaksi osaksi kaikissa asiakirjoissa, mutta kk. 1727 Pielilä, kk. 1841-47 Pietilä. Meri olettaa alkumuodon olleen *Pienelä tai *Pienilä, ja sekaannuksen johdosta on piälä myöhemmin konstruoitu Pieliläksi ja Pietiläksi.23 Askaisissa on Riihilä, rīlä, joskus rìhilä. MK 1540, 1555, 1556 Redilä, VA 6151556 Ridilä, VA 693a 1557 Redylä $\sim$ Reidile, VA 7471558 Reidile $\sim$ Ridhile, VA 796 1559 Ridhile $\sim$ Ridilä, VA 8541560 Rihile, VA 855 1560, VA 907 1561. Rihilen, VA 10471565 Rÿlä, jne. Yleisimmät merkinnät ovat 1560-luvulta alkaen Rÿlä ja Rihilä, mutta vielä VA 16051601 Red-

21 SCARIN-Faldentus, Wirmoensis In Finlandia Territorii Memorabilia 1. Abor 1741, s. 41.

22 Askaisten asumusnimistö, s. 121.

23 Meri, s. 128. 
dilä, VA 16261601 Redile Redelä. Koska nykyistä ääntämistä vastaava merkintä (Rÿlä) mainitaan jo v. 1565, on todennäköistä, että toista tavua alkava konsonantti on ollut puheesta kadonneena koko sen ajan, jolta asiakirjamerkintöjä on säilynyt. 24

Edellä on jo ollut puhe niistä vaihdoksista tai oikeastaan rinnakkaisnimitapauksista, joita suomalaisen ja ruotsalaisen nimenkäyttöpiirin kohtaaminen aiheuttaa. Useassa tapauksessa ruotsalainen nimi on äänteellisesti mukautunut suomalaiseen asuun. Päinvastaista kehitystä, siis suomalaisen nimen muuttumista ruotsalaiseen asuun, on paljon tapahtunut nykyisellä ruotsinkielisellä rannikkoalueella.25 Kustavissa on muutamia hyviä esimerkkejä ruotsalaisen nimen muuttumisesta suomalaiseksi: E $1 \mathrm{~m} n$ ä s, MK 1540 Elmenäs, on sekoittunut suomenkielisessä käytössä obliikvisijojensa (esim. elmnäsis) ansiosta (i)nen-loppuisiin suomalaisiin nimïn; siitä on tullut Elmnäinen (Lopmeri, s. 12). Tähän verrattavissa on Godels jö, MK 1540 Godelszö, josta on tullut koelsū. Kielestä toiseen siirtyminen on vienyt nimen suu-loppuisten luonnonpaikkaan viittaavien nimien joukkoon. S t r ö m b y, REA 1469 Strømby, Tk. 1695 Ströma, on saanut suomalaisten suussa asun ruani, kk. 1698-1712 Ruoni (Lopmeri, s. 147). Nimellä B o d a, VA 5851555 Bodhabÿ, on suomalainen, täysin äännelaillinen vastine puore (LopMERI, s. 11).

Alkuperäinen asu on kovasti muuttunut myös lemulaisessa nimessä $\mathrm{V}$ a $1 \mathrm{p}$ p e r i, joka tulee vanhasta aatelisnimestä Falkenberg (MK 1655 Falkenberg, 1722 Falckenbergh Walperi).

Yleensä ihmiset eivät tietoisesti johdattele nimissä tapahtuvia muutoksia. On kuitenkin tapauksia, joissa tietoinen ohjailu on ollut ilmeistä. Lapin pitäjässä on Kulla n p e rä, jonka vanhat merkinnät viittaavat alkuasuun $\mathrm{Ku} 11$ in p e r ä (FMU 1504 Kullinpera, VA 5181594 Kullinperre, MK 1655 Cullanperä). Muutoksen motiivina on ollut säädyllisyys. 26 Tässä ei ole syytä puhua nimen vaihtumisesta, sillä uusi muoto on varmasti määräytynyt sillä perusteella, että haluttiin vain vähän korjata vanhaa nimeä. Maskussa on vanha yksinäistila Kakka r a in en muutettu 1900 -

\footnotetext{
24 Askaisten asumusnimistö, s. 123.

25 Aulis OJa, mts. 77-78.

26 Meri, s. 87.
} 
luvulla Syväsaloksi. Tällaisia mutoksia tapahtui varsinkin 1800- ja 1900-luvuilla tilannimissä, kuten myöhemmin saamme nähdä. Tietoista nimen johdattelua on myös se, että Maskussa Sten berga, steimBeri, sai muutamia kymmeniä vuosia sitten vapaan käännöksen $\mathrm{L}$ in $\mathrm{n}$ a v u o r i melkein keskellä kylää olevan vuoren mukaan. Edellä on mainittukin, että Killuva palautettiin myös virallista tietä - alkuperäiseen muotoonsa Killinvaha.

Kun tarkastellaan kyliin kuuluvien maatilojen nimien muuttumista, tulee esiin muutamia vaikeuksia, joita on mahdoton voittaa. Suurimpana vaikeutena on, että ko. tilojen nimiä alkaa esiintyä säännöllisesti, muutamia poikkeuksia lukuunottamatta, vasta 1600 1700-lukujen vaihteen asiakirjoissa, lähinnä veroluetteloissa sekä henki- ja kirkonkirjoissa.

Tilannimet voidaan jakaa kahteen päätyyppiin. Toiset viittaavat johonkin tilan isäntään tai tilan erikoiseen ominaisuuteen (Anttila, Heikintalo, Kuppari, Seppälä). Tähän ryhmään kuuluvat nekin nimet, joitten syntyperuste tai sen lisäksi myös etymologia on vaikeasti tai ei ollenkaan selitettävissä (Tuppi, Keppi, Papu, Suutila, Kinnala, Maikola jne.). Useissa tapauksissa viimeksi mainitun tapaiset nimet ovat joskus tilaa pitäneen isännän lisänimiä — tosin jokin tällaisista nimistä on alunperin saattanut merkitä vain taloa. Selvästi vain taloa merkinneitä ovat esim. Kujanpää, Piha, Pinomäki, Niemi, Perhe, Frälssi jne. Toisen päätyypin nimien syntyperusteena on vertailu saman kylän talojen kesken (Ylitalo, Alitalo, Isotalo, Pohjatalo, Uusitalo). Tästä nimityypistä sanoo Eino JuTnkkaLA, että se on tullut ruotsalaiselta rannikolta päin suomalaiselle alueelle verrattain myöhään. ${ }^{27}$ Useimmissa tapauksissa kylän tilat kuuluvat samaan nimityyppiin, vaikka muutamia poikkeuksiakin on olemassa. Vanhat kirjurit suhtautuivat asiaan niin, että he merkitsivät edellisen ryhmän nimet (Mats Jacobsson Jussila, Hans Simola), mutta jälkimmäisen ryhmän nimiä alkaa näkyä vasta 1700-luvun alkukymmenillä, muutamissa pitäjissä vasta 1800 -luvun puolenvälin

27 Eino Juprkixala, Suomen talonpojan historia. Porvoo 1942, s. 333, 334. 
jälkeen. Ne tilannimet, jotka tavataan ennen 1690-lukua, kuuluvat kaikki ensiksi mainittuun nimiryhmään. Jos isännän nimen perässä ei 1700-luvun alkupuolella ole tilan nimeä, kuuluu ko. tila melkein kaikissa tapauksissa myöhempien asiakirjojen mukaan siihen ryhmään, jossa nimen perusteena on vertailu.

Suurin osa esillä olevan alueen pohjoisosan, siis vanhan Vehmaan kihlakunnan tilojen nimistä kuuluu ensiksi esitettyyn ryhmään. Raisiossa, Maskussa ja Askaisissa ovat molempien ryhmien suhteet suurin piirtein tasaveroiset, Askaisissa sittenkin enemmän ensimmäiseen ryhmään kuuluvia kuin muissa. Lemussa ja Merimaskussa on suurin osa vertailuun perustuvia nimiä. Naapuripitäjistä voidaan mainita, että Rymättylässä on melkein yksinomaan jälkimmäisen tyypin nimiä ja Ruskolla, Nousiaisissa, Mynämäessä ja Mietoisissa nimet kuuluvat suurimmaksi osaksi ensimmäiseen ryhmään.

Kyliin kuuluvien maatilojen nimiä on tähän esitykseen kertynyt materiaaliksi kaikkiaan vajaa tuhat, mutta läheskään kaikissa ei ole voitu havaita muutosta. Käsittelyn ulkopuolelle on jätetty ne tilat, jotka on muodostettu 1800-luvun lopulla ja tällä vuosisadalla.

Varhaisimmat asiakirjoissa säilyneet tilannimet ovat 1500-luvun puolivälin jälkeiseltä ajalta. Joukossa on sellaisiakin nimiä, joita ei enää tunneta, mutta osa niistä kuuluu hävinneille tiloille. Pyhänrannan, Pyhänmaan ja Raision pitäjistä on tätä kirjoitettaessa ollut käytettävissä isäntäluettelot 28 . Näistä käy selville, että omistajasuvun vaihtumisesta huolimatta tilan nimi yleensä säilyy. Pyhänrannan-Pyhänmaan pitäjistä tunnetaan nykyisistä tilannimistä 1500-luvulta ja 1600-luvun alusta kolmattakymmentä. Vain muutamaa poikkeusta lukuunottamatta omistajasuku on vaihtunut muutamia kertoja, mutta nimi on säilynyt. Samaan tulokseen päästään Raision tosin suppeampaa materiaalia tarkasteltaessa. Askaisista voidaan osoittaa joukko henkilöön perustuvia tilojen nimiä, joitten aiheena ollutta isäntää ei tavata 1600-luvulla tai joissakin tapauksissa koko sinä aikana, jolta säännöllisiä asiakirjamerkintöjä on olemassa. Näitten nimien on täytynyt syntyä viimeistään 1500-luvulla.29

28 Hormia, mts. 168-204. Raision osalta on R. A. MäNTYLän Raision historiaa varten laatima isäntäluettelo ollut käytössä.

29. Askaisten asumusnimistö, ss. 126-127. 
Muuallakin tässä tutkitulla alueella on joukko vanhoja nimiä, jotka tukevat em. pitäjistä saatuja tuloksia.30 Sama nimien yleinen vaihtumattomuus koskee 1700-luvulla asiakirjoihin tulevaa laajaa tilannimistöä. Muutamia vaihtumisia kuitenkin sattuu.

Kuten edellä on mainittu, tilojen nimet jakautuvat kahteen ryhmään, joista toisessa perustana on henkilö tai tilan funktio, toisessa vertailu. Yleensä saman kylän tilat kuuluvat muutamia poikkeuksia lukuunottamatta samaan ryhmään. Joskus nimi vaihtuessaan siirtyy ryhmästä toiseen:

Maskun Sopolasta mainitaan v. $1710 \mathrm{H}$ ann ula ja Gre u Ia, kk. 1808-1813 Hannula 1. Lillgård ja Greula 1. Storgård. Nykyään käytetään yleisimmin nimiä Vähätalo ja Is otalo, mutta toisetkin nimet muistetaan vielä. - Lankilassa on Länsitalo ja I täta l o (henkik. 1800 Västergård ja Östergård), mutta Ijk. 1796 Mattila ja Antila (Anttila). Aikaisemmin näitä tilannimiä ei ole asiakirjoissa esiintynyt, Koska muitten tilojen kohdalla on vastaavanlaiset nimet yleensä merkitty jo 1700-luvun alusta lähtien, on oletettavissa, että myöhemmin asiakirjoihin ilmestyneet tällaiset nimet ovat myöhemmin syntyneitäkin. Avoimeksi jää se seikka, onko tiloilla aikaisemmin mahdollisesti ollut vertailuun perustuvaa nimityyppiä vai ovatko ne olleet nimettömiä. Jälkimmäisessä tapauksessa pitäisi olettaa, että vertailutyypin kylissä ei tiloilla vielä 1700-luvun alussa ollut ollenkaan nimiä. - Kiveisissä on Alitalo ja Ylitalo (kk. 1808 Nedergård ja Övergård). Jälkimmäinen oli v:n 1797 lainhuudatuspöytäkirjassa Yrjäntalo, v. 1.839 Ylitalo l. Yrjäntalo; Ijp. 1832 Ali- eller Heikintalo ja Yli- eller Yrjäntalo. Karinkylässä oli $\mathrm{v}: \mathrm{n}$ 1808-1813 kirkonkirjojen mukaan Andintalo ja Heikintalo 1. Sillankorva ja Osala. Antintalosta käytetään myös nimeä I s o t a 10 (kk. 1836-1842 Storgård), ja Antintalo jää vähitellen unohduksiin. Isotalo jakautui kahtia; toisen osan nimenä on Isotalo eli $\mathrm{Kal}$ l e n t a lo, toisen $J u h$ a $\mathrm{t}$ a l o. Molemmista osista käytettiin henkikirjoissa vuosisadan lopulla nimeä Isotalo. Sillankorva muuttui 1870-luvulla Kantelmä eksi. Sillankorva jäi kuitenkin torpan

30 AuLrs OJA on tutkinut varsinaissuomalaisten talonnimien historiaa ja osoittaa, että 1500-luvun asiakirjoissa mainituista. Maarian 29 nimestä vaihtui 1600-luvulla vain neljä (Jaakolasta Simola, Kokista Knuuti, Pumposta Puolikk» ja Tupesta Prusi), lisäksi kolmen nimi lyheni (Leipähoususta Leipälä, Luukir. veestä Kirves ja Pyhästähengestä Henki). Hist. aikakausk. 1944, ss. 187-188. 
nimeksi. Tällä vuosisadalla Kustaantalolle on tullut rinnakkaisnimi Rannikko (sukunimi).

Luolavuoressa oli alkuaan kaksi tilaa, joista kummastakaan ei ole käytetty asiakirjoissa muuta kuin omistajan nimeä aina 1870 luvun lopulle asti. Toinen tiloista oli nimeltään $\mathrm{K} n$ a a $\mathrm{p}$ i ja toinen on vieläkin Simola. Knaapi jakautui kahtia 1800-luvun lopulla, ja näin syntyneiden tilojen nimiksi tuli U u sitalo ja $\mathrm{V}$ an hat a 1 o. Vanhastatalosta tuli vielä K eskitalo, kun Nousiaisista tullut nykyisen isännän isä toi mukanaan vanhan kotitilansa nimen. 31 Yleensä tilan jakautuessa säilyy uusien nimien perusosana alkuperäinen nimi, ja kumpaankin liittynyt prefiksi ilmoittaa eron, esim. Iso-Heikkilä ja Vähä-Heikkilä Kurittulan kylässä. Joskus alkuperäinen nimi supistuu saatuaan prefiksin, esim. Kurittulan Linnanpaltasta tuli Etupaltta ja Takapaltta. Aivan ahtaassa nimenkäyttöpiirissä kehitys saattaa mennä vieläkin pitemmälle. Tässä tapauksessa Etupaltasta on tullut rinnakkaismuoto Etutalo ja Takapaltasta Takatalo. Raisiossa on Vatselan kylässä Isotalo jaettu kahtia, jolloin ainakin virallisiksi nimiksi tulivat Yli-Isotalo ja Ali-Isotalo, näistä tuli puheessa ülìne ja alìne. Pyhänrannan Kukolassa on Tanila jaettu Kylä- ja Mäki-Tanilaksi; jälkimmäinen on lyhennettynä mäki (PNA). Polttilan Kl e mola on jaettu Yli- ja Ali-Klemolaksi. Siirtyminen ryhmästä toiseen on tapahtunut jo tässä vaiheessa, mutta Yli-Klemolasta käytetään rinnakkaisnimeä kesktalò. Kylän toisellakin tilalla, Perheellä, on rinnakkaisnimi pustel (PNA). Uusien, vertailuun perustuvien nimien epästaattisuudesta voidaan vielä mainita esimerkki Pyhänmaan Kettelin Vainio-Mikolasta. Sillä on rinnakkaisnimenä henkilöön perustuva arvomikla (PNA).

Samanlaisia kaksoisnimiä ovat Lemun Niittykartanossa $\mathrm{J} u \mathrm{~h}$ a ntalo Meritalo ja Fetuntalo Pohjatalo. Juha on Joh. Wilhelmsson ja Fetu Fredr. Wilhelmsson (Henkik. 1879). Juhantalo oli aikaisemmin Kallentalo, sitä piti Carl Henrik Henriksson '(lainhuudatuspöytäkirja v:lta 1852; 1866 Carl Nitugård). Niittykartano oli vielä 1700-luvulla yksinäistila. - Raukuisissa on Matintalo Perintötalo Raukuinen "ja Juhantalo Frälssi(ta lo) (lainhuudatuspöytäk. 1850 Pä-

31 Suullinen tieto ko. isännän pojalta. 
rintalo, 1896 Matintalo eli Perintötalo, henkik. 1879 Matintalo; lhpk. 1850 Johantalo, 1888 Johantalo eli Frälsitalo, henkik. 1879 Juhantalo). Tiloja piti v. 1830 (henkik.) Mats ja Johan, jotka saattavat olla nimien aiheina. Raukuisissa oli jo 1700-luvun alussa kaksi tilaa.

Askaisissa on Kaamaisten kylässä Alis- ja Ylis - Ka a ma in e n eli (Kaamaisten) Alistalo ja Ylistalo. Näistä on v. 1794 (Ijk.) käytetty nimiä Jacontalo ja Andintalo. Lempoisista mainitaan v. 1808 (kk.) Lillgård, Mellangård ja Storgård (käytössä ovat varmasti olleet suomalaiset vastineet), mutta nyt niminä ovat $\mathrm{J}$ a a kkola, Heikkilä ja J uhola $\sim \mathrm{Juhantalo,} \mathrm{joitten} \mathrm{aiheena}$ ovat 1700-1800-lukujen vaihteessa eläneet isännät.

Kustavin Koivulahdessa jakautuivat 1730—40-luvuilla Is okartano ja Koila (alk. kylän nimi), josta on myös käytetty nimeä $H$ e r r a k a r a n o (1700-luvun keskivaiheilla), molemmat kahtia. Jaettujen tilojen isännät olivat nimeltään Erik, Matti, Antti ja Heikki. Nykyään tilojen nimet ovat E e rikintalo, Matintalo, Antintalo ja $\mathrm{Heikintalo.} \mathrm{Tilikirjoissa} \mathrm{näitä} \mathrm{nimiä}$ ruvettiin käyttämään vasta 1800 -luvulla.

Taivassalon Rouhun kylässä on Ihanttula jaettu kahtia. Tiloja nimitetään kulloistenkin isäntien mukaan. 1920-luvulla nimet olivat Benhartintalo ja Suomisentalo (PNA, Arvo Merex kokoelmat vuosilta 1928-29).

Vehmaan Kiikoisten kylässä on ollut V in t o-niminen tila (MK 1722 Vinto, henkik. 1800 Wintta), josta 1800-luvun asiakirjoissa ruvettiin käyttämään nimeä Alastalo. Alastalo voi olla vanhempikin nimi, sillä kylässä on jo kauan ollut Ylistalo (MK 1722). Tässä on yksi harvoja 1700-luvun alusta säilyneitä tämän tyypin nimiä.

Laitilassa on Untamalan Vapola (MK 1722- henkik. 1830) muuttunut Ylikartanoksi (1805) ja siitä vielä U udeksikartanoksi. Kun nimeä Ylikartano alettiin käyttää, oli tilan juuri ottanut haltuunsa uusi suku, mutta Vapola esiintyi rinnakkaisnimenä senkin jälkeen. (Nyk. üskartan.) Vapolakin muistetaan vielä, mutta väitetään, että se olisi nykyinen Ventola (PNA). Muisti on pettänyt, sillä Vapola ja Ventola mainitaan samoissa asiakirjoissa kumpikin omana tilanaan, ja v:Ita 1835 (Ijp.) on merkintä Vapola eller Uusikartano. 
Tyyppien väliset muutokset ovat tapahtuneet pääasiassa Maskun, Lemun ja Askaisten pitäjissä, ts. sillä alueella, jossa molemmat nimityypit ovat suunnilleen yhtä voimakkaasti edustettuina. Jos jätämme Vehmaan Kiikoisten ja Laitilan Untamalan esimerkit hieman erityyppisinä sivuun, voidaan todeta, että ko. kylien tiloille ei ole 1700-luvun alussa merkitty nimiä (lukuunottamatta kustavilaista esimerkkiä, mutta Kustavi ei kuulukaan tämän ilmiön varsinaiseen alueeseen), ja myöhemmin niissä aina ovat henkilönnimikantainen ja vertailuun perustuva nimityyppi rinnakkain. Edelleen huomataan, että henkilöön perustuvat nimet ovat yleensä talo-loppuisia, eivätkä ne ole niin säilyviä, kuin vanhastaan tunnetut lajohtimiset, vaan ne vaihtuvat hyvinkin helposti isännän mukaan. Ominaista näissä on rinnakkaisnimisyys - kuten aina siellä missä nimet vaihtuvat; samalla tilalla voi olla kolmekin nimeä. Juhantalotyyppi ei kuitenkaan ole 1700 -luvun tuote, sillä sitä tavataan jo 1600-luvun asiakirjoissa ja se voi joskus vaihdella samassa nimessä la-tyypin kanssa.

Vertailuun perustuvan nimen muuttumisesta toiseksi, saman periaatteen mukaiseksi nimeksi on olemassa muutama esimerkki. Kustavissa on Anavaisten kylässä ollut Ä̈̈rit a l o (MK 1690 äritalo). V. 1703 (MK) siitä on käytetty nimeä $\ddot{A}$ rikylä, mutta v. 1710 (Kl.) on merkitty Westergård. Tila on vieläkin nimeltään Länsitalo. Vehmaan Ennyisissä vaihtelevat nimet Keskikylä (esim. henkik. 1710, 1761, 1800) ja K es kitalo (MK 1722), joista jälkimmäinen on 1800-luvulla yleistynyt ja lopulta kokonaan syrjäyttänyt edellisen. Keskikylä lienee varhainen muoto, sillä kylässä on myös Pääkylä (1710 Päkylä). Samanlaisia esimerkkejä olisi vielä muutama, mutta muutos niissä on hyvin toisarvoista laatua.

Henkilönnimikantaisen nimen vaihtumista toiseksi on joskus havaittavissa. Aina ei kuitenkaan isännän korkonimi, jota käytetään asiakirjoissa tilannimen funktiossa, pääse vakiintumaan.

Raision Kuloisten L ukkarlan isäntänä mainitaan v. 1559 Henrik luckari. Tässä näkyy joko miehen ammatti, korkonimi tai tilan vanha nimi. Tilan otti haltuunsa 1580 -luvulla turkulainen porvari Martti Isolusikka, jonka nimi säilyi tilalla vuoteen 1635. Miehen lisänimi ei jäänyt tilan nimeksi, vaikka hän itse viljelikin tilaa v. 1616-1630, vaan vanha nimi, muodossa Lukkarla, säilyi. Mahittulan Tuomola, joka mainitaan 1600-luvun alusta ( $v$ :n 1639 kirkon- 
tilien yhteydessä olevassa penkkijärjestysluettelossa Tuomoila merkinnee juuri tätä), lienee sama tila, jota 1540-50-luvuilla piti Tuomas Räiskä tai Räyskä (MK 1540 Räysk, 1543 Räÿsk, 1593 Reskiölä, viimeinen aivan varmasti tilan nimi).

Mälikkälän kylässä on kirjavuutta. 1700-luvulla tilojen nimet olivat Kankare, Huhko, Jonkki(la), Junnila ja Mattila. Näistä mainitaan 1500-luvulla vain ensimmäinen (1569 Kangar). Mattilan rälssiä on isännöinyt vv. 1621-1635 Henrik Handhi (?Hanhi), jonka jälkeen suku muuttuu. Suvunvaihdos tulee vielä muutaman kerran 1600-luvun kuluessa. V:n 1639 kirkontileissä (penkkijärjestys) tunnetaan 'Mälickäläst Mattila Hendrich Thomsō'. Han(d)hi lienee kuulunut yksin Heikille korkonimenä tai sukunimenä; tuskin se on koskaan kudunut tilalle, koska kirkonmiehetkin tiesivät tilan nimeksi Mattilan. Huhkon tilaa piti 1620--1650-luvuilla Matti Piipari. Huhko on vanha nimi ja se mainitaan em. kirkontileissäkin penkkijärjestyksessä: Matt Huhkoi i Mälickälä. Piipari on varmasti ammattinimi, oik. sotilastermi. Tosin se on saattanut jonkin aikaa olla tilankin nimenä; Matin suku on säilynyt 1700-luvulle asti, jolloin tilasta on käytetty taas nykyistä nimeä, Huhko. Huhko tuntuu hyvin vanhalta ja kuuluu oi-loppuisiin nimiin ( $\left.{ }^{*} \mathrm{hu}(\mathrm{u}) \mathrm{hkoi}\right)$. Joukkilan ja Junnilan vaiheet jäävät vielä selvittämättä, sillä 1500 luvulla mainitaan kylässä Matts Vaÿsu $(1569,1571)$ ja Matts Pë̈as (1562) päÿe (1568).

Kustavin Kevoista I. Stansholmasta mainitaan v. 1690. (MK) Wuotitalo, MK 1703 Vuotila. Tilan haltijana oli tässä vaiheessa ja vielä v. 1705 isännän, Antti Matinpojan, leski Beata, jolla oli Jaakko-niminen poika. V. 1710 isäntänä on Juho Eerikinpoika ja tilan nimeksi tuli J a a k o n t a lo, mikä sitten säilyykin. On huomattava, että nimien vaihdos ei yleensä kohta näy asiakirjoissa, eikä se puhekielessäkään liene nopeaa, sillä uusi ja vanha nimi elävät usein kauan rinnakkain.

Vehmaan Puostan Mattilasta on asiakirjoissa tullut 1700l:n puolivälin jälkeen E e rola (henkik. 1774 Erola l. Mattila). 1740-60-luvuilla tätä virkataloa ovat hallinneet aliupseerit, ja senkin jälkeen suku vaihtui muutaman kerran, mutta Eeroa ei näy ainakaan useampivuotisena haltijana. Kysymyksessä voi olla kaksi rinnakkain ollutta nimeä, joista toinen (Eerola) vähitellen pääsi voitolle. Aina on sekin mahdollisuus, että muualta siirtynyt isäntä tuo vanhan kotitilansa nimen mukanaan. 
Kalannin Kytämäessä on Yrjäntalosta tullut Simola. Ensimmäisissä kirkonkirjoissa ( $\mathrm{v}$ :sta 1690 alkaen) on Simola, mutta maallisissa tilikirjoissa Simola näkyy vasta 1760-luvulla ja Yrjäntalo vielä v:n 1800 henkikirjassa. Tilaa piti 1690-luvulla Simo Antinpoika, joka luovutti sen vävylleen Erkki Simonpojalle Vanhastakylästä. Maalliset asiakirjat ovat tässä ainakin 70 vuotta kirkollisista asiakirjoista jäljessä.

Velluan kylässä on käynyt niin, että vanhasta $M$ a tin t a l o s t a (MK 1690) tuli välillä Matinsimo (1722--1800), mutta myöhemmin vakiintui taas alkuperäinen Matintalo.

Pyhänmaan Pitkästäluodosta mainitaan v. 1690 (MK) Simon Mårtens. Maitil, MK 1703 Henr. Mattila, samoin henkikirjassa v. 1705. Saman isännän kohdalla mainitaan kastekirjassa v. 1703 Couhi ja v. 1710 (henkikirja ja Kl.) Henr. Simonsson Kouhi, joka melko varmasti on em. Simon poika. Nykyisin tila on Kouhi. Kouhi vaikuttaa vanhimpaan kerrostumaan kuuluvalta nimeltä. Mahdollisesti kysymyksessä on yleinen kaksinimisyys. Kylästä mainitaan v. 1560 (VA 878) nimet Buskoi ja Piitick (Piitikku?). Tilojen lukumäärän huomioonottaen täytyy toisen näistä kuulua Kouhiin. Kumpaakaan em. nimistä ei enää tunneta tilaa merkitsevänä, mutta pellonnimenä on pusko. Nykyään nimen arvellaan johtuvan pellon äärellä kasvavista viinimarjapensaista (PNA), mutta mielellään sen yhdistäisi 1500-luvun tilannimeen. Piitikku voi olla vain yhdelle isännälle kuulunut korkonimi. Tällaiset lisänimet ovat usein olleet tilannimen aiheena, mutta vain harvoin ne ovat syrjäyttäneet entisen nimen. Joka tapauksessa voidaan todeta, että nykyistä Kouhia on kutsuttu kolmella nimellä, joista ainakin kaksi (Mattila ja Kouhi) on ollut isännän vaihdoksesta riippumattomina tilanniminä.

Pyhänrannan Ylikylän I mpilästä mainitsee HormIA, että 1630-luvulla sitä viljelee suutari Yrjö Yrjönpoika Uudestakaupungista. Tila oli hylättynä 100 vuotta, ja sen rakennuksetkin hävisivät, mutta Simo Matinpoika Karru Valkamasta otti v. 1736 Impilän aution haltuunsa. Tila on vieläkin Simon suvulla. ${ }^{32}$ Se säilyi veroluetteloissa autiona ollessaankin nimellä Skomakare (MK 1690, Kl. 1705, 1710, MK 1722, 1730). Simon aikanakin siitä on merkintä Sutari (1761), mutta jo kastekirjassa v. 1735 Imbilä. Impilä voi olla

32 HoRm. A, mts. 191. 
tilan vanha nimi, jonka uusikaupunkilainen suutari tilapäisesti syrjäytti sadaksi vuodeksi, mutta joka kuitenkin kansan tiedossa säilyi tämän ajan. Toinen mahdollisuus on se, että Simo otti tilalle Impilän ns. harkinnaisnimenä. Varmaa on, että kotoaan hän ei sitä tuonut tullessaan, Karrun poika Valkamasta. Impilä, im Bl ̈̈, ei muuten ole kovin harvinainen nimi näillä main.

Vielä voidaan esitellä muutamia lajittelemattomia vaihdoksia:

Lokalahden Vartsaaressa on kaksi tilaa, T u isk u la ja O 11 a, yhtynyt. V. 1761 (henkik.) ne mainitaan vielä erikseen, mutta v. 1777 (Ijk.) Ollaa ei enää ole. Rajakartassa v. 1846 on Tuiskula eller Olla, saman kartan selityksessä vain Olla, samoin paria vuotta myöhemmässä vesialuekartassa. Jakokartassa v. 1860 on Tuiskula, samoin melkein kaikissa asiakirjoissa sen jälkeen. Paikkakuntalaiset tuntevat molemmat nimet, mutta Olla on yleisempi.

Kalannin Palsan kylässä on nimi $\mathrm{M}$ a t e ro, joka esiintyy jo maakirjassa v. 1690. Välillä tilasta käytettiin, ainakin asiakirjoissa, nimeä Markus (1722-1755). Tilaa piti jonkin aikaa Markus Olavinpoika. Samassa kylässä tuli nimestä R u onantalo (Kl. 17101722) R a n t a (henkik. 1740).

Laitilan Seppälän kylän nimissä on sattunut sekaannusta. V. 1710 (Kl.) mainitaan Jören Heiko,.MK 1722 Heikola. V. 1705 on merkitty yhden tilan nimeksi Heicka, samoin viittä vuotta myöhemmin. V. 1722 on kymmenysveroluettelossa Heÿka ja henkikirjassa Hieka. Viimeksi mainittu muoto säilyy, ja nykyään tila on H i e kka. Kylässä on myös ollut ainakin koko 1700-luvun Mälttärin tila (1705 Mältär). Se on ollut $\mathrm{H}$ eikolan vieressä, ja tiloilla on ollut jotain yhteistä, koska niistä molemmista käytettiin nimeä Mälttäri (Ijp. 1835 Gustav ja Daniel Mältaris, mutta vielä henkik. 1830 Mats Mältari ja Daniel Heikola). Myöhemmin 1800luvulla Mälttäri jäi pois käytöstä, Danielin talosta tehtiin Kyläheiko ja Kustaan talosta Vainioheiko.

Untamalan kylässä vaihtui $\mathrm{N}$ äveri (kl. 1710-1722 Näfweri) H a k k a r i ks i (henkik. 1722 Hackari). Tässä välissä vaihtui sukukin, mikä ei tosin merkitse sitä, että nimi juuri silloin olisi muuttunut, vaan muutos on saattanut tapahtua aikaisemminkin.

Laitilan Padon kylässä on $\mathrm{Kurki}$ muuttunut asiakirjoissa 1820-luvun lopulla Mikolaksi (henkik. 1828 Kurki, 1830 Mikola). V:n 1820 paikkeilla tuli uudeksi isännäksi Matti Matinpoika 
Hinnerjoelta. Hän ei voinut tuoda Mikola-nimeä tullessaan. Tilalle naitiin v. 1735 miniä Malkon Mikolasta. Tuntuu tosin kummalliselta, että tämä voisi olla nimen aiheena. Fhkä nimi on tietoisesti haluttu vaihtaa, mutta myöhemmin nimi ei ole voinut muualta päästä tilalle. Tässä on taas esimerkki, miten kauan uusi nimi voi olla vanhan rinnalla tulematta asiakirjoihin.

Kalannin Ruonanperässä oli v. 1562 Sorry (= S o r r i). Tilasta käytetään nimeä T u o kil a kirkonkirjoissa 1690-luvulta lähtien ja maakirjoissa $\mathrm{v}$ :sta 1730 lähtien. 1670-luvulta 1700-luvun alkupuolelle asti piti tilaa Matti Tuomaanpoika, jonka nimen jäljessä kirkonkirjoissa (1690-1701) oli Tuokila, mutta samassa yhteydessä hänen lastensa kohdalla Sorri. Merkinnät eivät kuitenkaan viittaa siihen, että tila olisi jakautunut. Maakirjassa v:lta 1655 mainitaan Thomas Sorry, joka on edellä mainitun Matin isä. Ei tunnu uskottavalta, että nimi olisi muuttunut saman suvun isännöidessä. Tämä ei ole ainoa Tuokila-nimi, joten on mahdollista, että se on siirtynyt joskus uuden isännän mukana muualta. Sorri on henkikirjassa vielä v. 1800 .

On koko joukko tapauksia, joissa nimeen ei nähtävästi ole oltu tyytyväisiä, vaan on haluttu kauniimpi nimi. Vaihdos ei ole tapahtunut itsestään, vaan tietoisen pyrkimyksen tuloksena. Näin lienee käynyt ainakin niissä tapauksissa, joissa vanhaan nimeen on liittynyt negatiivinen affekti.

Maskun Mäksmäestä on merkitty v. 1703 Jacob Kräki (MK, samoin kk. 1709-1736). Suku vaihtuu, ja v. 1710 tilan kohdalla on Grels Thomasson Tuomola. Saattaa tosin olla niin, että Kräki oli vain Jaakon lisänimi ja T u o m o l a tilan vanha nimi. Vehmaan Riihivainion kylässä on $\mathrm{T}$ u p p i vaihtunut joskus vuosien 1836 1844 välillä $\mathrm{K}$ eskit a loks i. Omistajakin on samalla vaihtunut.

Pyhässämaassa on Pyhänmaan kylässä vanha, jo 1500-luvulla esiintynyt Mustapää vaihdettu $R$ antataloksi 1800-luvulla (Hormis, mts. 198). Ehkä pyrkimyksenä on ollut nimen tekeminen kauniimmaksi silloinkin, kun Kauhianpään Pirvola (MK 1690 Pirgola) on muutettu 1870-luvulla Mäkeläksi.

Kalannissa on Elkkyisissä vanha, ilmeisesti sukunimeen perustura Krappe (mm. henkik. 1710 ) vaihtunut $M$ a rttilaksi. Uuden nimen aiheena oli Kammelan Marttilasta n. v. 1700 tullut uusi isäntä, entinen renki. Siivolan kylässä vaihtui $K$ u p p a ri 
H eikkiläksi, kun tila oli jaettu kahtia ja toisen puolen isännäksi tuli v. 1820 Heikki Juhonpoika Vehmaalta. Kun muistetaan, kuinka pitkän ajan esim. Padon Kurjen vaihtuminen Mikolaksi kesti, on tässäkin jätettävä avoimeksi mahdollisuus, että Heikkilä olisi jo kauemmin ollut tilan nimenä, vaikka sitä ei asiakirjoista näykään. Haudon $\mathrm{L}$ a iska vaihtui $\mathrm{L}$ a ukolaksi, kun tilan toisen puolen otti haltuunsa Isak Isakinpoika Lapin Laukolasta v. 1876 (muuttaneitten luettelo v. 1876, Kalanti). Tässäkin tapauksessa jaetun tilan molempien puolien nimi vaihtuu samaksi, vaikka uuden nimen tuoja piti hallussaan vain puolta tilaa. Siivotun kylässä vanhasta L a is k a s t a (1722-1837 Laiska) tehtiin U u s ik a r t a n o (lainhuudatuspöytäk. v. 1888). Varhelan S o r k k a vaihdettiin 1900-luvulla nimeksi U u sitalo. Muita uusia kalantilaisia muutoksia ovat Kallelan kylän $K o l h$ in vaihtuminen $P$ äi völäksi ja Pispan vaihtuminen Pietiläksi (PNA) sekä Inhamon Änniskylän vaihtuminen $R$ antalaksi.

Laitilan Vidjalan kylässä vaihdettiin vanha, ainakin 1600-luvulta peräisin oleva $\mathrm{P}$ ukki(l a) J un nilaksi v. 1790 (kirkonkirjojen mukaan), jolloin tilan otti haltuunsa sotamiehen poika Juho Niilonpoika Kalannin Kodjalan Lallasta. Hän ei voinut tuoda uutta nimeä tullessaan. Edellisen isännän isän, 1710-luvulla Pukkiin tulleen, v. 1680 syntyneen Matti Matinpojan jäljet johtavat Malkon Junnilaan. Vanha nimi elää kauan, sillä vieläkin tiedetään kylän entisen nimen olleen Pukkila (PNA). Soukaisten kylässä on vanhasta nimestä $V$ ä ärä luovuttu ja tilalle otettu keinotekoinen $\mathrm{H}$ a a $\mathrm{p}$ a s a a ri (lainhuudatuspöytäk. v. 1857).

YRJö Hormia on em. teoksessaan osoittanut monesti, mistä uusi isäntä on tullut, ja vaikka nimen muutos joskus saattaakin sattua isännänvaihdon aikaan, ei yhdessäkään näistä tapauksista entisen kotitilan nimi näy. Toisaalta on edellä ollut joukko tapauksia, joissa uusi suku on tuonut uuden nimen entiseltä kotitilaltaan. Kuitenkin ovat suvut vaihtuneet tiloilla monin verroin useammin kuin nimet, niin että nimen tuominen on vain poikkeus.

Tässä yhteydessä voidaan mainita muutama esimerkki siitä, että nimi on tuotu juuri muodostetulle tilalle. Vehmaalla jaettiin Putan kylän Isotalo kahtia. Toisen puolen nimenä säilyi Isotalo, mutta toisen nimeksi tuli Simola, sillä sen otti haltuunsa Juho Antinpoika Heikolan Simolasta (esim. henkik. 1722 ja 1761). Taivassalolainen 
"Eric Johansson Urnas" (Uurnan kylästä) osti Raision Vatselan kylän Vähästätalosta puolet (Raision tuomiok. 1806, syyskäräjät). Näin tuli Vatselan kylään tilannimi Uurna (PNA). Laitilan Torren Pärkölästä on lohkaistu Kudila; isäntä on tullut 1800-luvulla Männäisten Kudilasta. Saman kylän Lapro on jaettu kahtia. Toiselle osalle tuli isäntä Salon kylän Raulasta, toiselle Salon Seikolasta. Molemmat toivat nimen tullessaan (PNA). Näin kaikki Torren kylän tilannimet ovat nyt siirrynnäisnimiä. Uusissa tapauksissa vaikuttanee osaltaan sukunimien vakiintunut, lakiin perustuva käyttö.

Nimien vaihtuminen ei tapahdu nopeasti. Voidaan sanoa, että vaihtumisprosessi alkaa silloin, kun uusi nimi tulee vanhan nimen rinnalle, ja päättyy silloin, kun vanha nimi unohdetaan tai kun se tajutaan entiseksi nimeksi. Nimet voivat elää rinnakkain monien sukupolvien ajan. Joskus uusi tulokas ei jaksa säilyä, vaan vanha nimi tulee uudestaan käyttöön. Kun nimi vaihdetaan asiakirjoihin, on vaihtumisprosessi voinut alkaa aikoja sitten. Tili- ja henkikirjoissa saattaa syrjäytetty nimi säilyä toistasataakin vuotta kauemmin kuin kirkonkirjoissa.

On tapahtunut myös sellaista muuttumista, jossa nimi on joutunut äännelakien tai muitten samaan tapaan vaikuttavien ilmiöitten alaiseksi. Useimmissa tapauksissa alkuperäinen muoto on vielä tunnettavissa, mutta joskus kehitys on mennyt niin pitkälle, että on syntynyt ikään kuin uusi nimi.

Lokalahdella on Varanpään kylässä seuraava sarja: MK 1690 Rääti, Kl. 1705 Rätig, 1710 ja MK 1722 Rätilä, henkik. 1722 Rättylä, 1761 Ryttälä, 1800 Ryttsälä, nykyään rïttälä. Tähän on verrattavissa Kalannin Nästin P eits a lo: MK 1690 Pietil, 1703 Pietilä, Kl. 1705 Pietilä, 1710 Peitzala. Viimeinen merkintä jää asiakirjoissa pysyväksi, mutta murteessa nimi on peitla. Tässä on syytä muistaa lokalahtelainen kylännimi Pietinalho ( $<$ Pätsinalho), joka äännetään murteessa pätìalh (LopmerI, s. 118-119). Tuntuu siltä, että $\vartheta \vartheta>t t \sim t$ joskus häiritsee ympärillä olevia vokaaleja, ellei sana satu olemaan yleisesti tuttu.

Kalannin Lahdessa on käynyt näin: MK 1690 ja 1703 Pihanperä, Kl. 1710 Pere, MK 1722 Pihanpärä, henkik. 1740 Pärä, Kl. 1755 Perä, henkik. 1761 ja 1800 Perhe, mutta kk:ssa v:sta 1690 alkaen Perhe; nyk. P e rhe, perè (< pereh; OJansuo on kiinnit- 
tänyt huomiotaan siihen, että Rauman muxteen alueella ei ole tapahtunut $h: n$ metateesia ja että siellä esiintyvät metateesimuodot ovat lainoja 33 ). Lopussa olevan $\ddot{a}: \mathrm{n}$ muuttuminen $e: k s i$ lienee parhaiten selitettävissä niin, että nimi on ensin alkuosansa menetettyään sekaantunut lähellä oleviin Perhe-nimiin. Esim. aivan naapurikylässä, Kuuvantakana, on Toisperhe. Tosin Velluassa, myös naapurikylässä, on Pihanperä. Laitilan kylän $M$ atin e e r o (tähän viittaava merkintä kaikissa asiakirjoissa) on lyhentynyt muotoon martero. Tästä voi päätellä, että Kalannin Palsan M a t e r o (esim. MK 1690) on aikaisemmin varmaan ollut *Matineero. Askaisissa on Askaisten kylässä P o hjal a pohjala, Tk. 1727 Pohjala. Helposti saa sen käsityksen, että nimensyntyperusteena olisi talojen keskinäinen sijainti. Pohjala ei kuitenkaan ole pohjoisin kylän taloista. Maakirjoissa v. 1703 ja 1767 sama nimi on muodossa Pohialais, mikä viittaa alkumuotoon Pohjalainen. ${ }^{34}$

Kleemola on tavallisesti murteessa klemola tai klēmola, mutta Laitilan Soukaisissa se on liamla (PNA), vaikka asiakirjoissa on enimmäkseen Klemola. Muoto on tunnettu jo 1600-luvulla (kirkontilit v. 1681 Liemoila; samassa on merkitty Seppälään Liemola, nyk. klèmola).

Takavokaalit vaihtuvat usein vastaaviksi etuvokaaleiksi tai päinvastoin. Pyhänrannan Ylikylässä on narvela, VA 8781560 Narffü̈, MK 1690 Nerfvila, henkik. 1891 Nervilä. Nimi on aika yleinen Suomessa, mutta se on yleensä aina etuvokaalinen.35 Askaisissa on nä̈̈kölä, MK 1701 Naukela, 1703 Neykölä Naukela, 1722 Naukila, kk. 1769 Näykölä. Nimi tunnetaan Pohjanmaaltakin, ja siellä se on etuvokaalinen.35 Monet Pietilä- ja Heikkilä-nimet ovat VakkaSuomen pohjoisosassa takavokaalisia (piatla, heikla). Etuvokaalisiakin on ja joskus samastakin nimestä käytetään molempia asuja (PNA). Pyhänrannan Santiossa on hella, MK 1690 Hellilä, 1722 Hällä, samoin henkik. 1891. Laitilan Vidilässä on kindlä (PNA), asiak. Kinnala (esim. MK 1722, henkik. 1891).

Jos sisä- tai loppuheitto on osasta paradigmaa kuluttanut vokaalin pois, on vokaali säilyessään altis muutoksille. Pari esimerkkiä:

33 HeikKr OJansuU, Lounaismurteiden äännehistoria. Konsonantit, s. 100.

34 Askaisten asumusnimistö, s. 130.

35 Askaisten asumusnimistö, s. 128. 
Pyhänrannan Rohdaisissa on $\mathrm{H} \mathrm{elkk} \mathrm{ula,} \mathrm{Kl.} 1705$ Heikilä (po. Helkilä?), helklilä, helkkula, helkla. Varhonkylässä on K o n s a (yl. asiakirjoissa), konsi, adess. konsil, 1600 -1:n al. Consul (Hormra mts. 175). Kalannin Ruonanperässä on Tuokila ( $v$ :sta 1690 lähtien) $\sim$ tuak(o)la. Tässä yhteydessä voidaan eri tapauksena mainita Maskun Pakaisten rasè rasì (ed. tunnetaan paikkakunnalla vanhemmaksi), MK 1701 Rase.

Alkuaan vahva-asteinen nominatiivi voi muuttua heikkoasteiseksi. Kysymyksessä lienee lähinnä yleisesti tunnettu genetiivin käyttö nimen perusmuotona, mutta muutamissa tapauksissa obliikvisijoilla on muuten vain ollut vaikutusta kehitykseen. Äännelaillisia ovat Kalannin Peteksen ja Palsan $\mathrm{R}$ a $\mathrm{nta}$ a, ranna (Palsassa myös Tammi, tamme) sekä Hallun $\mathrm{P} \mathrm{e} \mathrm{k} \mathrm{k} \mathrm{a,} \mathrm{pekà.} \mathrm{Lähinnä} \mathrm{kai} \mathrm{viimeksi}$ mainitun mukaan on Kalannin Hallussa $\mathrm{N}$ is s i(lä), nisì, Kallelassa Hassu, hasù, Laitilan Kodjalassa J u s s i, jusì, samoin Pyhämaan Kursilassa Jussi(la), jusì. Geminaatalliset muodot ovat vallitsevina asiakirjamerkinnöissä kaikissa em. nimissä.

Analogian tiliin lienee laskettava Laitilan Salon ja samoin Elkkyisten L a ssila, lastla, lukuisien Pietilä, piatla, Anttila, andla, (V)uotila, uatla nimien mukaan.

Pieniä muutoksia voitaisiin luetella pitkältikin, mutta suurimmaksi osaksi nimistä voidaan äännelait tuntien helposti huomata alkuperäinen muoto.

Mauno Koski: Über den Wechsel und die Veränderungen der Dorf- und Gehöftnamen in einigen südwestfinnischen Kirchspielen

Das Material dieser Untersuchung lieferten die Namensverzeichnisse der alten Gerichtsbezirke von Vehmaa sowie der Kirchspiele Lemu, Askainen, Merimasku und Raisio. Im ganzen gibt es über 600 Dorfnamen und etwa 1000 Namen solcher Gehöfte, die zu Dörfern gehören.

Die Namen der Dörfer und der diesen gleichzusetzenden alten Einzelgehöfte sind im allgemeinen - zum mindesten vom Jahre 1550 an - unverändert; von dieser Zeit an sind uns auch regelmässige Verzeichnisse von Dorfnamen erhalten. Vereinzelte ältere Aufzeichnungen stützen die Auffassung, dass die Dorfnamen des MittelaIters sich auch späterhin nicht veränderten. Einen unverkennbaren Namenwechsel gibt es nur in einigen seltenen Fällen. 
Jeder Name ist in einem bestimmten Kreis bekannt und wird dort gebraucht. Einen solchen Kreis könnte man Namengebrauchskreis nennen. Dieser erweitert sich mit der Zunahme des Verkehrs. Bei den Dorfnamen ist in dieser Hinsicht ganz besonders das Stadium beachtenswert, in dem aus dem Kirchspiel unter dem Einfluss sowohl administrativer als sozialer Faktoren ein fester sozialer Kreis wurde. In einigen Fällen sind in ein und demselben Kirchspiel an verschiedenen Orten gleichlautende Dorfnamen entstanden. In dem Gebiet, das als Grundlage für diese Darstellung untersucht wurde, haben die Namen sich nicht in ihrer ursprünglichen Gestalt erhalten, sondern sich - wenigstens teilweise - rerändert, in den meisten Fällen mit Hilfe eines Präfixes oder irgendeiner anderen namensvorangestellten Bestimmung, z.B. Joki- und MetsäSylttylä in Raisio, Piuha- und Korpi-Iiroinen in Masku, Manner- und SalmenKaisti in Vehmaa. Die ursprüngliche Gestalt der Namen ist noch weiterhin verändert worden, als die Dörfer von Lemu und Askainen (vormals eine Kapellengemeinde von Lemu) namens Järvinen sich zu einem Namengebrauchskreis vereinigten. Aus dem am Meere, südlicher gelegenen Järvinen in Askainen wurde Merijärvi (meri 'Meer' und in der Mundart dazu 'Süd') und aus dem Järvinen in Lemu entstand Mannerjärvi (manner 'Festland'). Von siedlungsgeschichtlichem Standpunkt aus betrachtet ist es durchaus möglich, dass das eine der im Beispiel genannten Dörfer aus dem anderen hervorgehen konnte; sie sind jedoch nicht als geteilte Dörfer anzusehen in dem Sinne wie z.B. die nebeneinander liegenden Dörfer Iso- und Vähä-Vallunen in Lemu. Nebeneinander finden wir auch die ursprünglich gleichlautenden Namen in Kalanti: Isokorpi und Jaakkolan- oder Vähäkorpi. In beiden Fällen hat der Name ursprünglich einen Ort bedeutet, die Besiedlung erfolgte jedoch von mehreren Dörfern aus. Nach dem Zusammenschluss der Namengebrauchskreise mussten der Deutlichkeit halber die Namen verändert werden.

Weil infolge des Namenwechselprozesses Doppelbenennungen entstehen, muss in diesem Zusammenhang beachtet werden, dass vor allem in den Grenzgebieten des finnischen und schwedischen Sprachgebiets einige Gehöfte sowohl einen finnischen als einen schwedischen Namen tragen, die beide oftmals ganz verschiedener Herkunft sind.

Noch allgemeiner als der Wechsel ist bei den Dorfnamen die Veränderung, die relativ häufig den Lautgesetzen folgt. Die Kürzung der Namen mit der Endung laksi (lahti = Bucht) zu -la [z.B. in Rymättylä: Sandlax (Grundbuch aus dem Jahre 1540) > Santala] kommt in den alten Grosskirchspielen Vehmaa und Taivassalo, in Rymättylä und in vereinzelten Streufällen auch anderswo vor. Das Zentrum der Erscheinung liegt im Mundartengebiet von. Vehmaa und Taivassalo, wo sie mit der Apokope, die dort häufiger vorkommt als in anderen Kirchspielen, in Verbindung zu setzen ist. Eine ähnliche Abschleifung macht sich auch bei anderen Namen bemerkbar, manchmal ist sogar die Volksetymologie mit im Spiel. Als eine Art lautliche Entwicklung sind auch die Fälle anzusehen, wo ein schwedischer Name eine finnische Fassung erhält.

Von dem mehr oder weniger unmittelbaren Namenwechsel getrennt muss der bewusste Namenwechsel oder die Namensänderung behandelt werden. In diesen Fällen sind meistens ästhetische Gesichtspunkte entscheidend gewesen. 
Die Namen der Gehöfte bestehen aus zwei Haupttypen: die einen beziehen sich auf irgend einen Hofbesitzer oder eine besondere Eigenschaft des Gehöfts. Zu dieser Gruppe zählen auch die Namen, deren Entstehungsgründe oder die Etymologie schwer zu erklären sind. Zum zweiten Haupttyp zählen die durch einen Vergleich zwischen den Gehöften eines Dorfes entstandenen Namen (z.B. Yli- und Alitalo, Ober- und Unterhof). In den meisten Fällen gehören die Namen eines Dorfes zu demselben Typ. Zum zweiten Haupttyp zählende Namen tauchen verhältnismässig spät, oftmals erst im 19. Jahrhundert, in den Urkunden auf.

Im Gerichtsbezirk von Vehmaa dominieren die Namen der ersten Kategorie. In Masku, Raisio und Askainen sind die Proportionen der Gruppen ziemlich ausgeglichen. In Lemu und Merimasku beruhen die Namen grösstenteils auf den obenerwähnten Vergleichen. Auch bei einem Namenwechsel behalten die Namen der Gehöfte in den meisten Fällen ihren Grundtyp bei; ein Übergang von einer Gruppe in die andere findet in solchen Gebieten statt, wo die Gruppen in gleichem Verhältnis stehen. In derartigen Fällen haben die Namen einen in viel grösserem Masse provisorischen Charakter, als wenn der Name zur ersten Kategorie gehört, d.h. auf den Namen des Hofbesitzers oder eine Eigenschaft des Gehöfts zurückgeht.

In den Urkunden aus dem 16. und 17. Jahrhundert ist eine ganze Reile alter Gehöftnamen erhalten, die grösstenteils noch in Gebrauch sind, obgleich die meisten Gehöfte schon mehrfach den Besitzer gewechselt haben. Es gibt jedoch auch Fälle, wo ein Wechsel des Besitzers auch einen Namenwechsel zur Folge hatte. Auf der anderen Seite kann die Beobachtung gemacht werden, dass der grösste Teil der Fälle von Namenwechsel mit dem Wechsel des Bauerngeschlechts verknüpft ist. Oftmals verändert sich der Name nicht sogleich, sondern der Veränderungsprozess beginnt, indem ein neuer Name sich neben den alten stellt, und endet mit dem Verschwinden des alten Namens. Der Prozess dauert Jahrzehnte, manchmal sogar ein paar hundert Jahre. In den Urkunden verändern sich die Namen oft erst lange nach dem Erscheinen des neuen Namens neben dem alten. Manchmal kommt der neue Name in den Kirchenbüchern sogar ein halbes Jahrhundert früher als in den weltlichen Urkunden vor.

Meistens verändert sich ein Name, wenn der neue Hofbesitzer den Namen seines Geburtshofs mit auf den neuen Hof bringt oder der Name des Gehöfts aus dem Vornamen des Besitzers hergeleitet wird.

Die bewusste Veränderung des Namens aus ästhetischen Rücksichten ist auch bei Gehöftnamen ziemlich weit verbreitet. Ein derartiger Wechsel vollzieht sich meistens bei der Übernahme des Hofes durch ein neues Geschlecht. 